\title{
Microbiological Contamination of Reindeer Carcass During Slaughter
}

\author{
By $A$. Vaarala and $H$. Korkeala
}

Department of Food and Environmental Hygiene, University of Veterinary Medicine, Helsinki, Finland.

\begin{abstract}
Vaarala, A. and H. Korkeala: Microbiological contamination of reindeer carcass during slaughter. Acta vet. scand. 1994, 35, 383-388. - Microbiological counts for 10 different sampling sites of 28 reindeer carcasses were studied in 3 reindeer slaughterhouses in Finland. On each carcass the hindshank, round, abdomen, flank, brisket, foreleg, shoulder, neck, foreback and back were sampled immediately after slaughter, using a nondestructive swabbing method. The overall mean bacterial count for 10 sampling sites of reindeer carcasses was $1.51 \pm 0.51 \log _{10} \mathrm{cfu} / \mathrm{cm}^{2}$. Statistically significant differences were detected between sampling sites. The back part of the reindeer carcass, i.e. hindshank, round, back and foreback, seemed to be relatively clean. The most contaminated parts were the foreleg, brisket and abdomen (2.05-2.95 $\left.\log _{10} \mathrm{cfu} / \mathrm{cm}^{2}\right)$; these could be used for monitoring the hygiene of the reindeer carcass after slaughter. Differences between the 3 slaughterhouses were detected for some sampling sites, which may be due to differences in slaughter techniques and hygiene.
\end{abstract}

hygiene; microbiology; aerobic plate count; slaughterhouse.

\section{Introduction}

Reindeer (Rangifer t. tarandus L.) husbandry is important as a traditional source of livelihood in northern parts of Finland. The production of reindeer meat has increased during the last decade (Rahkio \& Korkeala 1989). The number of reindeer slaughtered annually in 1990-92 has been about 175.000 individuals, corresponding to approximately 4 million $\mathrm{kg}$ of meat (Anon. 1992, 1993).

Due to the special character of reindeer husbandry the slaughtering of semi-domesticated reindeer differs from that of domestic animals. Reindeer are slaughtered seasonally from September till the end of February, when the average temperature varies from $5^{\circ} \mathrm{C}$ to $-15^{\circ} \mathrm{C}$. Slaughterhouses are usually located far away from inhabited places. Reindeer slaughtering is performed in plant abattoirs, which resemble ordinary slaughterhouses or in field slaughterhouses, which are built of lighter structures, such as a mere roof and floor, or simple moveable balks set up in the forest. The exact timing of slaughter and the number of reindeer slaughtered are impossible to know beforehand, since they depend on the movements of the reindeer, the availability of food and natural conditions.

There is limited information on the microbiological quality of the reindeer carcass after slaughter. It is also not known to what extent different parts of reindeer carcass are contaminated during slaughter. The only report on the microbiological quality of the reindeer carcass known to the authors is the study by Petäjä et al. (1987). They studied the microbiological quality of reindeer carcasses $0-5$ days after slaughter, using 2 sampling sites on each carcass. Petäjä et al. did not actually study the contamination of the different parts of the carcass immediately after slaughter. The purpose of this study was to determine the mean 
Table 1. Mean bacterial counts and standard deviations for different sampling sites of reindeer carcasses.

\begin{tabular}{lccc}
\hline $\begin{array}{l}\text { Sampling } \\
\text { site }\end{array}$ & $\begin{array}{c}\text { Number } \\
\text { of } \\
\text { samples }\end{array}$ & $\begin{array}{c}\text { Mean bacterial } \\
\text { count } \\
\log _{10} \mathrm{cfu} / \mathrm{cm}^{2}\end{array}$ & $\begin{array}{c}\text { Standard } \\
\text { deviation }\end{array}$ \\
\hline Hindshank & 27 & $0.78_{\mathrm{ab}}$ & 1.00 \\
Round lat. & 27 & $0.31_{\mathrm{a}}$ & 0.58 \\
Abdomen & 26 & $2.05_{\mathrm{cd}}$ & 1.03 \\
Flank & 28 & $1.63_{\mathrm{c}}$ & 1.00 \\
Brisket & 28 & $2.95_{\mathrm{e}}$ & 0.54 \\
Foreleg & 27 & $2.79_{\mathrm{de}}$ & 0.80 \\
Shoulder & 28 & $1.61_{\mathrm{c}}$ & 0.94 \\
Neck & 28 & $1.51_{\mathrm{bc}}$ & 1.28 \\
Foreback & 28 & $0.74_{\mathrm{a}}$ & 0.82 \\
Back & 25 & $0.48_{\mathrm{a}}$ & 0.75 \\
\hline
\end{tabular}

a-e: Different subscripts within a column indicate significant differences $(\mathrm{p}<0.05$, Tukey's test) between bacterial counts. cfu: Colony forming units.

bacterial contamination of reindeer carcass after slaughter, with particular attention to the level and distribution of contamination on different parts of the carcass.

\section{Materials and methods}

\section{The sampling procedure}

The survey was carried out in October 1991 in 3 reindeer slaughterhouses in Northern Finland. Two of the slaughterhouses (A and B) were field slaughterhouses and 1 (C) was a plant abattoir. Each slaughterhouse was visited on one occasion. A total of 28 reindeer carcasses were sampled, 8-10 carcasses at each slaughterhouse. Ten sites were sampled: hindshank, round (lateral), abdomen, flank, brisket, foreleg (plantar), shoulder, neck (lateral), fore-back and back (Fig.1), every other carcass on the left side and every other on the right. Samples were taken from the outer surface of the reindeer carcass at the end of the slaughtering. A total of 272 samples were analysed.
The sampling area $\left(25 \mathrm{~cm}^{2}\right)$ was marked with a sterile template and sampled with 2 cottonwool swabsticks ( $1 \mathrm{~cm}$ in diameter) moistened with $0.9 \% \mathrm{NaCl}$-solution. The swabstick was pressed forcefully against the sampling area and rotated during the sampling procedure. The 2 sticks were used perpendicularly to each other. After the sampling the cotton swabs were placed in a bottle containing $25 \mathrm{ml}$ of peptone water $(0.1 \%$ peptone $)$. The bottles were transferred to the laboratory chilled within $7 \mathrm{~h}$ after sampling and examined immediately.

\section{Microbiological analyses}

The bottles with the samples were shaken vigorously so that the cotton were evenly distributed in the peptone water. Aerobic plate counts (APC) were determined using the pour plate method (Anon. 1986) with plate count agar (Difco, Detroit, USA). The incubation was performed at $25^{\circ} \mathrm{C}$ for 4 days.

\section{Statistical analyses}

The statistical program Systat 5 (Systat 5 for the Macintosh, Systat Inc., USA) was used for statistical analyses. The counts were analysed in logarithmic form (Roberts et al. 1980), with bacterial counts less than $2 \mathrm{cfu} / \mathrm{cm}^{2}$ receiving a logarithmic value of $0\left(\log _{10} \mathrm{cfu} / \mathrm{cm}^{2}\right)$.

\section{Results}

Microbiological quality of reindeer carcasses The overall mean bacterial count for the 10 sampling sites was $1.51 \pm 0.51 \log _{10} \mathrm{cfu} / \mathrm{cm}^{2}$. The mean bacterial counts and standard deviations for the different sampling sites are shown in Table 1 . Round, back, foreback and hindshank had the lowest bacterial counts (APC $<1.00 \log _{10} \mathrm{cfu} / \mathrm{cm}^{2}$ ), foreleg, brisket and abdomen the highest (APC $>2 \log _{10} \mathrm{cfu} / \mathrm{cm}^{2}$ ) (Fig. 1).

One-way analysis of variance showed statistically significant differences $(\mathrm{p}<0.001)$ be- 


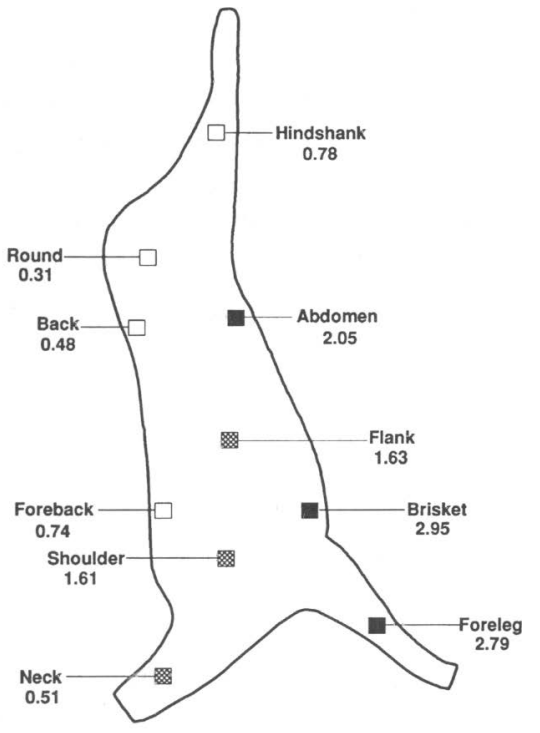

Mean bacterial count $\left(\log _{10} \mathrm{cfu} / \mathrm{cm}^{2}\right)$

$$
\begin{array}{ll}
\square & <1.00 \\
& 1.00-2.00 \\
\square & >2.00
\end{array}
$$

Fig u re 1. The mean bacterial counts $(\log 10 \mathrm{cfu} /$ $\mathrm{cm}^{2}$ ) of 10 sampling sites of reindeer carcasses.

tween the bacterial counts of sampling sites. According to the results of Tukey's pairwise comparisons the sampling sites could be divided into 3 groups differing significantly from each other in bacterial counts. Round, back, foreback and hindshank formed one group, neck, shoulder, flank and abdomen another and foreleg and brisket the third. No significant difference, however, was found between the bacterial counts of hindshank and neck or foreleg and abdomen. The bacterial counts of sampling sites within the groups did not show any differences.

Friedman's two-way analysis of variance showed that the level of contamination on different sampling sites in each individual reindeer
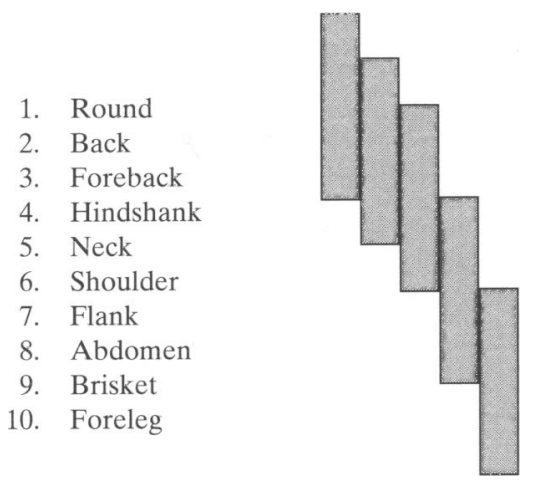

Figure 2. Order of systematic contamination of reindeer carcass. Sampling sites not connected by a column differ significantly from each other $(\mathrm{p}<0.05$, Friedman's analysis of variance). The level of contamination increases from 1 to 10 .

carcass followed a certain order $(\mathrm{p}<0.001)$. Further pairwise comparisons showed that round, back, fore-back and hindshank were significantly more often cleaner than foreleg, brisket, abdomen or flank (Fig. 2).

Spearman's rank correlation test showed strong positive correlations between the bacterial counts of brisket, foreleg and their nearby parts of the reindeer carcass: shoulder, flank, neck, foreback and back (Table 2).

\section{Comparison of slaughterhouses}

The mean bacterial count of reindeer carcasses slaughtered in slaughterhouse B was significantly higher $(\mathrm{p}<0.001)$ than those in slaughterhouses $\mathrm{A}$ and $\mathrm{C}$, as shown by oneway analysis of variance and Tukey's pairwise comparisons (Table 3). The mean bacterial counts for slaughterhouses $\mathrm{A}$ and $\mathrm{C}$ did not differ significantly.

Differences were found between the bacterial counts of sampling sites by the fully factorial analysis of variance (MANOVA). An interaction of sampling site and slaughterhouse was also observed, suggesting that differences in 
Table 2 . Statistically significant $(\mathrm{p}<0.05)$ correlations between sampling sites of reindeer carcasses.

\begin{tabular}{lccccc}
\hline & Hindshank & Brisket & Foreleg & Shoulder & Foreback \\
\hline Round lat. & 0.37 & & & & \\
Abdomen & 0.36 & & & & \\
Flank & & 0.33 & 0.46 & 0.45 & \\
Foreleg & & 0.62 & & & \\
Shoulder & 0.36 & 0.54 & 0.59 & 0.53 & 0.48 \\
Neck & & 0.58 & 0.79 & & 0.40 \\
Foreback & & 0.61 & 0.71 & & \\
Back & & 0.41 & 0.47 & & \\
\hline
\end{tabular}

Table 3. Mean bacterial count and standard deviation of reindeer carcasses in 3 slaughterhouses.

\begin{tabular}{lcc}
\hline Abattoir & $\begin{array}{c}\text { Number } \\
\text { of } \\
\text { carcasses }\end{array}$ & $\begin{array}{c}\text { Mean bacterial count } \\
\pm \mathrm{sd} \\
\left(\log _{10} \mathrm{cfu} / \mathrm{cm}^{2}\right)\end{array}$ \\
\hline $\mathrm{A}$ & 8 & $1.13 \pm 0.30_{\mathrm{a}}$ \\
$\mathrm{B}$ & 10 & $2.06 \pm 0.34_{\mathrm{b}}$ \\
$\mathrm{C}$ & 10 & $1.25 \pm 0.23_{\mathrm{a}}$ \\
\hline
\end{tabular}

a-b: Different subscripts within a column indicate significant differences ( $p<0.05$, Tukey's test) between abattoirs.

the bacterial counts of sampling sites vary among slaughterhouses. A comparison of the contamination of sampling sites between slaughterhouses by Tukey's test showed that slaughterhouse B had statistically significantly higher bacterial counts than slaughterhouses $\mathrm{A}$ and $\mathrm{C}$ for brisket, foreleg, neck and foreback (Table 4). No differences were found in the contamination of any sampling site between slaughterhouses $\mathrm{A}$ and $\mathrm{C}$. The bacterial counts of brisket and foreleg were high in all 3 slaughterhouses compared with other sampling sites. The bacterial count of abdomen was especially high in slaughterhouse A.

\section{Discussion}

The overall mean bacterial counts of reindeer carcasses in the present study were lower than those reported by Petäjä et al. (1987). However, the samples in their study were taken from the round and shoulder of the reindeer carcass, using a destructive method in 2 slaughterhouses 0 5 days after slaughter. The mean bacterial count of 65 carcasses was $5.18 \pm 0.22 \log _{10} \mathrm{cfu} / \mathrm{g}$. In the present study the mean bacterial counts of all 10 sampling sites of the reindeer carcasses seemed to be lower than the counts of domestic animal carcasses in other studies using various sampling sites, varying on beef $2-5 \log _{10}$ $\mathrm{cfu} / \mathrm{cm}^{2}$ and on pork 3-4 $\log _{10} \mathrm{cfu} / \mathrm{cm}^{2}$ (Roberts 1980, Johanson et al. 1983, Stolle 1988). The most important hygienic problem in slaughtering is to remove the hide, head, hooves and alimentary tract in such a way as to prevent contamination of the carcass meat (Roberts 1980). It has been shown that excessive dung on the hide increases the microbiological surface contamination of the carcass in cattle (Ridell \& Korkeala 1993). Living in the wild, reindeer are usually visually clean of faecal material and soil. If the slaughter occurs when there is snow on the ground, as is usually the case, the reindeer are even cleaner, which may partly explain the lower contamination of reindeer carcass.

The present study indicates that certain areas of the reindeer carcass seem to be significantly more contaminated than others. The most contaminated parts of the carcass - the foreleg, brisket and abdomen - are rather dirty ar- 
Table 4. Bacterial counts and standard deviations $\left(\log _{10} \mathrm{cfu} / \mathrm{cm}^{2}\right)$ of different sampling sites in 2 field slaughterhouses (A and B) and 1 plant abattoir (C).

\begin{tabular}{|c|c|c|c|c|c|c|}
\hline \multirow[t]{2}{*}{ Sampling site } & \multicolumn{6}{|c|}{ Abbatoir } \\
\hline & A & & B & & $\mathrm{C}$ & \\
\hline Hindshank & $0.62 \pm 0.95$ & $(8)^{1}$ & $1.04 \pm 1.25$ & (9) & $0.67 \pm 0.82$ & (10) \\
\hline Round lat. & $0.04 \pm 0.11_{\mathrm{a}}^{\mathrm{a}}$ & (8) & $0.73 \pm 0.84_{b}^{a}$ & (9) & $0.15 \pm 0.26_{\mathrm{ab}}^{\mathrm{a}}$ & (10) \\
\hline Abdomen & $2.69 \pm 1.41_{a}^{a}$ & (7) & $1.79 \pm 1.07_{\mathrm{a}}^{\mathrm{o}}$ & (9) & $1.84 \pm 0.45_{\mathrm{a}}^{\mathrm{a}}$ & (10) \\
\hline Flank & $1.10 \pm 0.79_{a}$ & $(8)$ & $2.00 \pm 1.06_{a}$ & (10) & $1.69 \pm 1.00_{\mathrm{a}}$ & (10) \\
\hline Brisket & $2.56 \pm 0.22_{a}^{a}$ & $(8)$ & $3.46 \pm 0.46_{b}$ & (10) & $2.76 \pm 0.41_{a}$ & (10) \\
\hline Foreleg & $2.24 \pm 0.15_{a}^{a}$ & $(8)$ & $3.73 \pm 0.46_{b}$ & (9) & $2.38 \pm 0.55_{a}^{a}$ & (10) \\
\hline Shoulder & $0.78 \pm 0.90_{a}^{a}$ & (8) & $2.21 \pm 0.73_{b}$ & (10) & $1.66 \pm 0.71_{\mathrm{ab}}^{\mathrm{a}}$ & (10) \\
\hline Neck & $0.60 \pm 1.03_{\mathrm{a}}$ & $(8)$ & $2.78 \pm 0.81_{b}$ & (10) & $0.96 \pm 0.73_{\mathrm{a}}$ & (10) \\
\hline Foreback & $0.17 \pm 0.34_{\mathrm{a}}$ & $(8)$ & $1.67 \pm 0.60_{b}$ & (10) & $0.26 \pm 0.25_{\mathrm{a}}$ & (10) \\
\hline Back & $0.64 \pm 1.08_{a}$ & $(8)$ & $0.78 \pm 0.62_{a}$ & (8) & $0.07 \pm 0.20_{\mathrm{a}}$ & (9) \\
\hline
\end{tabular}

$1_{\mathrm{N}}$ Number of samples. a-b: Different subscripts within a row indicate significant differences $(\mathrm{p}<0.05$, Tukey's test) between slaughter houses.

eas on other animals as well (Ingram \& Roberts 1976, Roberts 1980, Johanson et al. 1983, Stolle 1988). The technique used in reindeer slaughtering affects the bacterial counts detected on the carcass. The most contaminated parts of the reindeer carcass were on the front part of the carcass, where high positive correlations between sampling sites were also found. This indicates that when unhygienic handling of the carcass occurs in some sites of that area it affects many nearby parts of the carcass. When removing the hide from the brisket, legs and abdomen, some slaughtermen use hands and arms as well as knives; this may partly explain the contamination. The partially flayed hide can turn back during the slaughter process and touch the skinned surface of the carcass. This may also cause contamination, especially on the abdomen and brisket. The end of the neck is usually hairy and dirty and is therefore washed with a handheld device. In some slaughterhouses the forelegs are unnecessarily washed at the same time so that bacteria may be spread from the neck to the forelegs. The present study shows that the area of round, hindshank, foreback and back immediately after slaughter is relatively cleaner than on domestic animals. During slaughter this area is not touched by hands or tools because of the hide stripper used in these reindeer slaughterhouses. This may be one reason for the lower contamination of this area.

In slaughterhouse B higher bacterial counts were detected both for the reindeer carcasses as a whole and for the foreleg, brisket, neck, foreback and shoulder. In this slaughterhouse, unlike the others, the forelegs were washed. It was also observed that the water used in slaughterhouse B came from a small pond; the quality of the water has not been examined. In the other slaughterhouses the water came from the public water supply. The quality of the water in slaughterhouse B may have been poor, thus partly accounting for the high bacterial counts of the areas where water could have been splashed.

The present study showed that microbiological contamination of the reindeer carcass immediately after slaughter varies according to sampling site. The most contaminated sites 
were the foreleg, brisket and abdomen representing the typical contaminated area of the reindeer carcass. Compared to domestic animal carcasses the total bacterial counts of reindeer carcasses were lower and the back part of the carcass relatively cleaner. Further studies of reindeer slaughtering in different kinds of slaughterhouses, especially in field and plant slaughterhouses, are needed in order to be able to evaluate the quality of reindeer meat and hygienically important factors.

\section{Acknowledgements}

This study was supported by the Finnish Ministry of Agriculture and Forestry and the Finnish Veterinary Science Foundation.

We would like to thank VMD Erkki Pöysti, the head of the Municipal Food Laboratory of Rovaniemi and the laboratory staff for co-operation during the study.

\section{References}

Anonymous: Aerobic micro-organisms. Enumeration at $30^{\circ} \mathrm{C}$ in meat and meat products. Nordic Committee on Food Analysis 1986, no 86, 2nd ed., Espoo, Finland, 5 p.

Anonymous: Kertomus Paliskuntain yhdistyksen toiminnasta vuodelta 1991, (Report of the Finnish Reindeer Owner's Association of the year 1991).Poromies 1992, (2), 5-17.

Anonymous: Kertomus Paliskuntain yhdistyksen toiminnasta vuodelta 1992, (Report of the Finnish Reindeer Owner's Association of the year 1992).Poromies 1993, (2), 7-21.

Ingram $M$, Roberts TA: The microbiology of the red meat carcass and the slaughterhouse, Roy. Soc. Hlth. J.1976, 96, 270-276.

Johanson L, Underdal B, Grosland $K$, Whelehan $O P$, Roberts TA: A survey of the hygienic quality of beef and pork carcasses in Norway, Acta vet. scand. 1983, 24, 1-13.

Petäjä E, Suominen M, Puolanne E: Poron vientiteurastusta koskeva hygienia- ja tervalihaisuustutki- mus, (Investigation on the hygiene and incidence of DFD-meat of slaughtering at export slaughter houses for reindeer). Helsingin Yliopiston lihateknologian laitoksen julkaisuja, Helsinki, 1987, No.392.

Rahkio M, Korkeala H: Poronlihan tarkastustiedot Suomessa vuosina 1980-1986, (Reindeer (Rangifer tarandus) meat inspection in Finland in 19801986). Suom. Eläinlääkäril.1989, 95, 13-20.

Ridell J, Korkeala H: Special treatment during slaughtering in Finland of cattle carrying an excessive load of dung; meat hygienic aspects. Meat Sci. 1993, 35, 223-228.

Roberts TA: The effects of slaughter practices on the bacteriology of the red meat carcass. Roy. Soc. Hlth J. 1980, 100, 3-9.

Roberts TA, MacFie HJH, Hudson WR: The effec of incubation temperature and site of sampling on assessment of the numbers of bacteria on red meat carcasses at commercial abattoirs. J.Hyg.Camb. 1980, 85, 371-380.

Stolle FA: Establishing microbiological surveillance programmes at slaughterlines-a new concept of meat hygiene. Meat Sci. 1988, 22, 203-211.

\section{Sammanfattning \\ Mikrobiologisk förorening av renkroppar vid slakt.}

Bakterierantalet på 10 olika provställen av 28 renkroppar blev undersökt vid 3 renslakterier i Finland. Prov togs från varje kropp från lägg, stek, mage, sida, bringa, framben, bog, hals, framrygg och rygg genast efter slakt med en non-destruktiv, strykande metod. Det totala bakteriologiska medelvärdet av de 10 provställena på renkropparna var $1.51 \pm 0.51 \log _{10}$ $\mathrm{cfu} / \mathrm{cm}^{2}$. Statistiskt signifikanta skillnader konstaterades mellan provställena. Bakre delen av renkroppen d.v.s.-läggen, steken, ryggen och framryggen visade sig vara relativt ren. De mest förorenade delarna var framben, bringa och mage (2.05-2.95 $\log _{10}$ $\left.\mathrm{cfu} / \mathrm{cm}^{2}\right)$. Dessa partier kunde användas vid övervakningen av renkroppshygienen efter slakt. Skillnader i slaktteknik och -hygien mellan de undersökta slakterierna kan förklara skillnaderna i bakteriekontamination på olika provställen.

(Received February 16; accepted August 18, 1994).

Reprints may be requested from: H. Korkeala, Department of Food and Enviromental Hygiene, University of Veterinary Medicine, P. O. Box 6, SF-00581 Helsinki, Finland. 